\title{
Analisis Return on Assets dalam Menilai Pertumbuhan Laba Perusahaan
}

\author{
Wike Stevani 1), Nuraidha 2) \\ 1 Sekolah Tinggi Ilmu Ekonomi Tribuana \\ 2 Program Studi S1 Manajemen \\ wikestevani@stietribuana.ac.id \\ nuraidha@student.stietribuana.ac.id
}

\begin{abstract}
This study aims to determine how the Return On Assets in assessing the company. This study uses a qualitative method consisting of two variables, namely Return On Assets as the independent variable and Profit Growth as the dependent variable. The data analysis method used in this research is the analysis of Return On Assets in assessing the company's profit growth. The test results show that the average Return On Assets of $49.39 \%$ per year as a whole is categorized as very good, when viewed from the general standard or industry average, which is less than 30\%. Based on the results of these studies that Return On Assets in assessing Profit Growth has a contribution of 0.76\%. This can be proven by the results of research that each Return On Assets changes by 1 rupiah will be followed by changes in Profit Growth of 0.54 which means that Return On Assets is very significant in assessing Profit Growth.
\end{abstract}

Key Words: Return On Assets, Profit Growth

\section{Abstrak}

Penelitian ini bertujuan untuk mengetahui bagaimana Return On Asset dalam menilai Perusahaan. Penelitian ini menggunakan metode kualitatif yang terdiri dari dua variabel yaitu Return On Assets sebagai variabel independen dan Pertumbuhan Laba sebagai variabel dependen. Metode analisis data yang digunakan dalam penelitian ini adalah analisis Return On Assets dalam menilai pertumbuhan laba perusahaan. Hasil pengujian menunjukan bahwa rata-rata Return On Assets sebesar 49,39\% pertahun secara keseluruhan dikategorikan sangat baik, bila dilihat dari standar umum atau rata-rata industri yaitu kurang dari 30\%. Berdasarkan hasil penelitian tersebut bahwa Return On Assets dalam menilai Pertumbuhan Laba memiliki kontribusi sebesar 0,76\%. Hal ini dapat dibuktikan dengan hasil penelitian bahwa setiap Return On Assets mengalami perubahan sebesar 1 rupiah akan diikuti oleh perubahan Pertumbuhan Laba sebesar 0,54 yang berarti sangat signifikan Return On Assets dalam menilai Pertumbuhan Laba.

Kata kunci: Return On Assets, Pertumbuhan Laba

\section{PENDAHULUAN}

Di era globalisasi persaingan bisnis antar perusahaan semakin ketat. Di dalam dunia usaha, pencapaian laba (profit) merupakan salah satu tujuan dari sebuah perusahaan. Tingkat profitabilitas mencerminkan kemampuan perusahaan dalam memperoleh keuntungan dan tingkat efisiensi atas penggunaan asset perusahaan serta merupakan satu aspek yang penting sebagai acuan oleh investor atau pemilik dalam menilai kinerja perusahaan. Peneliti memprediksi mengenai prospek perusahaan tersebut dan mampu untuk memprediksi deviden yang akan diterima dimasa mendatang, laba 
dapat memberikan sinyal yang positif mengenai prospek perusahaan dimasa depan tentang kinerja perusahaan, dengan adanya pertumbuhan laba yang terus meningkat dari tahunke tahun, akan memberikan sinyal positif mengenai kinerja perusahaan. Menurut Windy (2012:2)

Menurut Ikatan Akuntansi Indonesia (2012:12), "Penghasilan bersih (laba) sering digunakan sebagai ukuran kinerja atau dasar bagi ukuran yang lain seperti imbal hasil investasi (Return On Investment) atau laba per saham (Earning Per Share)". Kinerja keuangan perusahaan secara umum perlu dilakukan analisis terhadap laporan keuangan, mencakup perbandingan kinerja perusahaan dengan perusahaan lain dalam industri yang sama dan evaluasi kecenderungan posisi keuangan perusahaan sepanjang waktu. Laporan keuangan perusahaan melaporkan baik posisi perusahaan pada suatu waktu tertentu maupun operasinya selama beberapa periode yang lalu.

Melihat kondisi perekonomian Negara kita saat ini, banyak perusahaan yang ingin berusaha menunjukkan kinerja terbaik dibidangnya masing-masing agar dapat bertahan dalam dunia bisnis, dan setiap perusahaan harus berhati- hati dalam mengambil keputusan terutama dibidang keuangan perusahaan, hal ini disebabkan karena kegagalan atau keberhasilan usaha hampir sebagian besar ditentukan oleh kualitas keputusan yang berkaitan dengan keuangan. Laporan keuangan merupakan salah satu sumber informasi penting bagi para pemakai laporan keuangan dalam rangka pengambilan keputusan ekonomi. Ukuran yang sering digunakan dalam rangka mengambil keputusan ekonomi sebagai suatu kebijakan perusahaan itu sendiri. Ukuran yang sering digunakan untuk menganalisis laporan keuangan dan performance yaitu hasil perputaran rasio profitabilitas. (Marpaung, 2021a)

Profitabilitas ratio sebagai mengukur kemampuan perusahan untuk menghasilkan laba dengan menggunakan sumber-sumber yang dimiliki perusahaan, seperti aktiva, modal atau penjualan perusahaan. Terdapat beberapa cara untuk mengukur besar kecilnya profitabilitas salah satunya yaitu Return On Assets (ROA) Menunjukkan kemampuan perusahaan dengan menggunakan seluruh aktiva yang dimiliki untuk menghasilkan laba setelah pajak, rasio ini penting bagi pihak manajemen untuk mengevaluasi efektivitas dan efisiensi manajemen perusahaan dalam mengelola seluruh aktiva perusahaan. Semakin besar Return On Assets (ROA), berarti semakin efisien penggunaan aktiva perusahaan atau dengan kata lain dengan jumlah aktiva 
yang sama bisa dihasilkan laba yang lebih besar dan sebaliknya (Nurlia, 2018:68-69).

Hipotesis dalam penelitian ini adalah melihat dari segi pentingnya Return On Assets (ROA) yang berperan bahkan berpengaruh terhadap Laba Perusahaan. Di dalam penelitian ini juga terdapat dampak positif dan signifikan terhadap Return On Assets (ROA) dan Laba Perusahaan.

\section{METODOLOGI PENELITIAN}

Menurut Zuldafrial (2012:46), sumber data adalah subjek dari mana data dapat diperoleh. Adapun cara memperoleh data tersebut dengan cara:

1. Observasi melalui link resmi perusahaan yaitu www.kimiafarma.co.id.

2. Penelitian ke perpustakaan menulis mencari referensi ke perpustakaan dengan membaca, mempelajari dari buku-buku, referensi yang ada hubungan nya dengan penelitian ini. Objek dalam penelitian ini yaitu variabel Return On Assets (ROA) sebagai variabel bebas atau independen dan variabel Pertumbuhan laba sebagai variabel terikat atau variabel dependen.

Selanjutnya, Jenis data terbagi menjadi dua jenis, yaitu:

a. Data Primer, yaitu:

Data yang langsung dikumpulkan sendiri oleh perseorangan suatu organisasi langsung menuju objeknya.

b. Data Sekunder

Data sekunder adalah data yang diperoleh atau dikumpulkan oleh orang yang melakukan penelitain dari sumbersumber yang telah ada. Data yang digunakan dalam penelitian ini adalah data sekunder. Data sekunder berupa data laporan keuangan yang diambil atau diakses melalui halaman resmi www.kimiafarma.co.id.

$$
\text { Menurut Sugiyono }
$$
teknik pengumpulan data merupakan langkah yang paling strategi dalam penelitian, karena tujuan utama dari penelitian adalah mendapatkan data. Tanpa mengetahui teknik pengumpulan data, maka peneliti tidak akan mendapat data yang mempengaruhi standar yang ditetapkan.

a. Studi Pustaka

Studi pustaka, dimana untuk mengkaji dan pendalaman dalam memecahkan permasalahan, maka peneliti menggunakan kepustakaan dengan membaca buku-buku, jurnal, dan yang berkaitan dngan topic penelitian yang dibahas.

b. Dokumentasi

Teknik yang digunakan dalam penelitian ini dengan cara mengumpulkan dan mendokumentasikan data-data laporan keuangan perusahaan dari tahun 
2015-2019 yang telah tersedia disitus resmi www.kimiafarma.co.id.

Menurut Sugiyono (2017:102) instrumen penelitian adalah suatu alat yang di gunakan untuk mengukur fenomena alam maupun sosial yang di amati. Dalam penelitian kualitatif, yang menjadi instrumen utama adalah peneliti itu sendiri. Penelitian kualitatif berfungsi menetapkan fokus penelitian, memilih informan sebagai sumber data, melakukan pengumpulan data, meneliti kualitas data, menafsirkan data dan membuat kesimpulan atas temuannya. Berdasarkan penjelasan diatas instrumen dalam penelitian ini adalah peneliti itu sendiri/instrumen utama, laptop, software pengolah data. Menurut Misbahuddin dan Iqbal (2013), analisis data dapat berbentuk seperti berikut:

1. Analisis Kuantitatif

Analisis Kuantitatif yaitu suatu alat analisis yang menggunakan model-model, seperti model matematika, model statistik, dan ekonometrik.

\section{Analisis Kualitatif}

Analisis Kualitatif yaitu analisis data yang dilakukan terbatas pada teknik pengolahan datanya, seperti pada pengecekan data dan tabulasi.

Analisis data yang digunakan dalam penelitian ini adalah analisis kualitatif, yaitu dengan menjelaskan tabeltabel dan angka-angka yang tersedia, kemudian melakukan uraian dan penafsiran serta dibuat kesimpulan. menganalisis data meggunakan rumus rasio keuangan sebagai berikut:

\section{Return On Assets (ROA)}

$\mathrm{ROA}=\underline{\text { Laba Bersih }} \times 100 \%$

Total Aktiva

\section{Pertumbuhan Laba}

Dengan Rumus :

$\underline{\text { Laba Bersih TS - laba bersih TL } \times 100 \%}$

Laba Bersih Tahun Lalu

Sugiyono (2016:270) Uji keabsahan data dalam metode kualitatif meliputi uji, credibility (validitas internal), transferability (validitas eksternal), dan confirmability (obyektivitas). Sugiyono (2016:270) juga dapat menjelaskan bahwa Uji kredibilitas data atau kepercayaan terhadap data hasil penelitian kualitatif antara lain digunakan dengan perpanjangan pengamatan, peningkatan ketekunan dalam penelitian, triangulasi, diskusi dengan teman sejawat, analisis kasus negatif, dan membercheck.

Mengingat pentingnya efektif dan efisien suatu perputaran total asset dalam menilai penurunan dan peningkatan laba perusahaan. Maka, penulis tertarik untuk mengkaji lebih dalam bagaimana Return 
On Assets dengan mengambil objek penelitian di PT. Kimia Farma (Persero) Tbk., yang merupakan perusahaan industri farmasi pertama di Indonesia dan salah satu Badan Usaha Milik Negara Republik Indonesia yang bergerak dibidang usaha jasa penyediaan jasa dan produk layanan kesehatan terintegrasi yang bermutu tinggi dan berdaya saing kuat pada bidang industry kimia, farmasi, biologi, dan kesehatan..

Penelitian ini data yang diambil adalah data laporan keuangan perusahan yang sudah di publikasi melalui web resmi PT Kimia Farma Tbk. yaitu www.kimiafarma.co.id. Data yang diambil tersebut sudah valid dan sudah diaudit jadi tidak diperlukan pengujian kredibilitas data.

\section{HASIL DAN PEMBAHASAN}

PT. Kimia Farma (Persero) Tbk selalu mengalami peningkatan penjualan bersih. Untuk Pencapaian kinerja Laba Bersih Perseroan pada tahun 2019 hanya sebesar Rp 15.890 juta turun 97,03\% dibandingkan tahun sebelumnya sebesar Rp 535.085 juta. Hal ini disebabkan oleh tidak tercapainya target Penjualan yang memiliki potensi marjin kotor cukup signifikan, kenaikan Beban Usaha untuk mempersiapkan pencapaian Penjualan yang agresif, kenaikan Beban Keuangan dari Investasi/Capex dan tidak tercapainya target penerimaan Piutang. Selain itu, proyek pengembangan pabrik bahan baku obat dan perluasan jaringan ritel farmasi di Arab Saudi belum memberikan kinerja laba yang positif hingga tahun 2019. Namun demikian, pencapaian EBITDA Perseroan tahun 2019 relatif masih cukup baik, yaitu sebesar Rp.695.942 juta.

PT. Kimia Farma (Persero) Tbk. merupakan salah satu Badan Usaha Milik Negara Republik Indonesia yang bergerak di bidang usaha farmasi atau penyediaan jasa dan produk layanan kesehatan dengan kepemilikan $90.025 \%$ dimiliki oleh Negara Republik Indonesia $9.975 \%$ dimiliki oleh umum yang beralamat di Jl. Veteran No.9, Jakarta Pusat Indonesia.

Laporan posisi keuangan PT. Kimia Farma (Persero) Tbk yang digunakan penulis dalam laporan ini adalah laporan keuangan periode 20152019 yang telah diaudit. Berikut laporan keuangan periode 2015- 2015 PT. Kimia Farma (Persero) Tbk.: 
Tabel 4.1

Laporan Keuangan PT. Kimia Farma (Persero) Tbk. Periode 2015-2019

\begin{tabular}{|c|c|c|c|}
\hline Tahun & Penjualan & Laba Bersih & Total Aset \\
& Bersih & & \\
\hline 2015 & 4.860 .371 & 187.943 .098 & 3.236 .224 \\
\hline 2016 & 5.811 .503 & 246.893 .143 & 4.612 .563 \\
\hline 2017 & 6.127 .479 & 323.866 .692 & 6.096 .149 \\
\hline 2018 & 7.454 .115 & 775.702 .104 & 9.460 .427 \\
\hline 2019 & 9.400 .535 & 4.780 .373 & 18.352 .877 \\
\hline
\end{tabular}

(Dalam Jutaan Rupiah)

Sumber: Data Diolah Laporan Keuangan PT. Kimia Farma (Persero)Tbk.

Dari tabel diatas dapat dijelaskan bahwa penjualan bersih PT. Kimia Farma (Persero) Tbk pada tahun 2015-2019 terus mengalami kenaikan pada tahun 2016 sebesar Rp. 5.811.503, pada tahun 2017 naik sebesar Rp. 6.127.479, pada tahun 2018 juga mengalami kenaikan sebesar Rp. 7.454.115 dan pada tahun 2019 mengalami kenaikan sebesar $\mathrm{Rp}$. 9.400.535. Nilai laba bersih pada tahun 2015 sampai 2016 mengalami kenaikan sebesar Rp. 58.950.045, dan mengalami kenaikan pada tahun2017 sebesar Rp. 76.973.549, pada tahun 2018 juga mengalami kenaikan sebesar Rp. 451.835.412 lalu pada tahun 2019 mengalami penurunan sebesar
Rp.770.921.731. Total Asset pada tahun 2015-2016 mengalami kenaikan sebesar Rp. 1.376.339. Pada tahun 2017 mengalami kenaikan sebesar Rp. 1.483.586, pada tahun 2018 mengalami kenaikan sebesar Rp. 3.364.278 dan mengalami kenaikan pada tahun 2019 sebesar Rp. 8.892.450.

Hasil pengembalian atas aset merupakan rasio yang menunjukkan seberapa besar kontribusi aset dalam menciptakan laba bersih. Dengan kata lain, rasio ini digunakan untuk mengukur seberapa besar jumlah laba bersih yang akan dihasilkan dari setiap rupiah dana yang tertanam dalam total aset. Rasio ini dihitung dengan membagi laba bersih 
terhadap total aset. Semakin tinggi hasil pengembalian atas aset berarti semakin tinggi pula jumlah laba bersih yang dihasilkan dari setiap rupiah dana yang tertanam dalam total aset. Sebaliknya, semakin rendah hasil pengembalian atas aset berarti semakin rendah pula jumlah laba bersih yang dihasilkan dari setiap rupiah dana yang tertanam dalam total aset.

\section{Tabel 4.2}

\section{Standar rata-rata industri Return On} Assets

\begin{tabular}{|l|c|}
\hline \multicolumn{2}{|c|}{ Return On Assets } \\
\hline$\%$ & Kriteria \\
\hline$>30$ & Sangat baik \\
\hline 30 & Baik \\
\hline 25 & Kukup \\
\hline 20 & Sangat Kurang \\
\hline$<20$ & \\
\hline
\end{tabular}

Sumber: Kasmir (2013:134)

Selengkapnya, ini merupakan hasil dan pembahasan Return On Assetspada PT. Kimia Farma (Persero) Tbk periode 2015-2019. Cara perhitungannya dengan memakai Return On Assets pada PT. Kimia Farma (Persero) Tbk periode 20152019. Tingkat Return On Assets pada PT. pada PT Kimia Farma (Persero) Tbk, pada tahun 2015 di peroleh laba bersih sebesar Rp. 187.943.098 dan total asset sebesar Rp. 3.236.224. Berikut ini adalah perhitungan Return On Assets pada tahun 2015:

$$
\begin{aligned}
R O A & =\frac{187.943 .098}{3.236 .224} \times 100 \% \\
& =58,7 \%
\end{aligned}
$$

Return On Assets pada PT. Kimia Farma (Persero) Tbk pada tahun 2015 adalah 58,07\%. Artinya setiap 1 perubahan asset akan di ikuti perubahan laba bersih sebesar $58,07 \%$ dan berdasarkan standar rata-rata industri untuk Return On Assets adalah >30\%, itu artinya keadaan perusahaan PT. Kimia Farma (Persero) Tbk dalam kriteria "sangat baik" karena sudah diatas standar rata-rata industri.

Tingkat Return On Assets pada PT. Kimia Farma (Persero) Tbk, pada tahun 2016 di peroleh laba bersih sebesar Rp. 246.893.143 dan total asset sebesar Rp. 4.612.563. Berikut ini adalah perhitungan Return On Assets pada tahun 2016.

$$
\begin{aligned}
R O A & =\frac{246.893 .143}{4.612 .563} \times 100 \% \\
& =53,2 \%
\end{aligned}
$$

Return On Assets pada PT. Kimia Farma (Persero) Tbk pada tahun 2016 
adalah 53,52\%. Artinya setiap 1 perubahan asset akan di ikuti perubahan laba bersih sebesar 53,52\% dan berdasarkan standar tandar rata-rata industri untuk Return On Assets adalah $30 \%$, itu artinya keadaan perusahaan PT. Kimia Farma (Persero) Tbk. dalam kriteria "sangat baik" karena sudah diatas standar rata-rata industri. Tingkat Return On Assets pada PT. Kimia Farma (Persero) Tbk, pada tahun 2017 di peroleh laba bersih sebesar Rp. 323.866.692 dan total asset sebesar Rp.6.096.149.

$$
\begin{aligned}
R O A & =\frac{323.866 .692}{6.096 .149} \times 100 \% \\
& =53,12 \%
\end{aligned}
$$

Return On Assets pada PT. Kimia Farma (Persero) Tbk pada tahun 2017 adalah 53,12\% Artinya setiap 1 perubahan asset akan di ikuti perubahan laba bersih sebesar 53,12\% dan berdasarkan standar rata-rata industri untuk Return On Assest adalah $>30 \%$,itu artinya keadaan perusahaan PT. Kimia Farma (Persero) Tbk dalam kriteria "sangat baik" karena sudah diatas standar rata-rata industri.

Tingkat Return On Assets pada PT. Kimia Farma (Persero) Tbk, pada tahun 2018 di peroleh laba bersih sebesar Rp. 775.702.104 dan total asset sebesar Rp. 9.460.427. Berikut ini adalah perhitungan
Return On Assets pada tahun 2018.

$$
\begin{aligned}
R O A & =\frac{775.702 .104}{9.460 .427} \times 100 \% \\
& =81,99 \%
\end{aligned}
$$

Return On Assets pada PT. Kimia Farma (Persero) Tbk pada tahun 2018 adalah 9,94\%. Artinya setiap 1 perubahan asset akan di ikuti perubahan laba bersih sebesar 9,94\% dan berdasarkan standar rata-rata industri untuk Return On Assets adalah $>30 \%$,itu artinya keadaan perusahaan PT. Kimia Farma (Persero) Tbk dalam kriteria "sangat baik" karena sudah diatas standar rata-rata industri. Tingkat Return On Assets pada PT. Kimia Farma (Persero) Tbk, pada tahun 2019 di peroleh laba bersih sebesar Rp. 4.780.373 dan total asset sebesar Rp. 18.352.877. Berikut ini adalah perhitungan Return On Assets pada tahun 2019.

$$
\begin{aligned}
R O A & =\frac{4.780 .373}{18.352 .877} \times 100 \% \\
& =0,26 \%
\end{aligned}
$$

Return On Assets pada PT. Kimia Farma (Persero) Tbk pada tahun 2019 adalah $0,26 \%$. Artinya setiap 1 perubahan asset akan di ikuti perubahan laba bersih sebesar 0,26\% dan berdasarkan standar rata-rata industri untuk Return On Assets adalah $>30 \%$, itu artinya keadaan 
perusahaan PT. Kimia Farma (Persero) Tbk dalam kriteria "Sangat kurang" karena sudah dibawah standar rata-rata industri.

Selanjutnya, Peneliti akan membahas hasil dan pembahasan Pertumbuhan Laba Pada PT. Kimia Farma (Persero) Tbk. periode 2015-2019. Tingkat Pertumbuhan Laba Pada PT. Kimia Farma (Persero) Tbk, pada tahun
2015 di peroleh laba bersih tahun 2014 sebesar Rp. 187.943.098 dan laba bersih 2014 sebesar Rp. 263.890.829.

Pertumbuhan Laba pada PT. Kimia Farma (Persero) Tbk pada tahun 2015 adalah -0,28. Tingkat Pertumbuhan Laba Pada PT.Kimia Farma (Persero) Tbk, pada tahun 2016 di peroleh laba bersih tahun 2016 sebesar Rp. 246.893.143 dan laba bersih 2015 sebesar Rp. 187.943.098.

\section{Perhitungan Pertumbuhan Laba pada tahun 2016}

$$
\text { Pertumbuhan Laba }=\underline{246.893 .143-187.943 .098} \times 100 \%
$$

187.943 .098

Pertumbuhan Laba pada PT. Tbk., pada tahun 2017 di peroleh laba Kimia Farma (Persero) Tbk pada tahun 2016 adalah 0,31. Tingkat Pertumbuhan Laba Pada PT.Kimia Farma (Persero) bersih tahun 2017 sebesar Rp. 323.866.692 dan laba bersih 2016 sebesar Rp. 246.893.143.

\section{Pertumbuhan Laba pada tahun 2017}

$$
\begin{aligned}
\text { Pertumbuhan Laba } & =\frac{323.866 .692-246.893 .143}{246.893 .143} \times 100 \% \\
& =0,31
\end{aligned}
$$

Pertumbuhan Laba pada PT. Tbk, pada tahun 2018 di peroleh laba Kimia Farma (Persero) Tbk pada tahun bersih tahun 2018 sebesar Rp. 2017 adalah 0,31. Tingkat Pertumbuhan 775.702.104 dan laba bersih 2017 sebesar Laba Pada PT.Kimia Farma (Persero) Rp. 323.866.692.

\section{Gambar 3}

\section{Pertumbuhan Laba pada tahun 2018}

Pertumbuhan Laba $=\underline{775.702 .104-323.866 .692} \times 100 \%$ 


$$
=1,39
$$

Pertumbuhan Laba pada PT. Tbk, pada tahun 2019 di peroleh laba Kimia Farma (Persero) Tbk pada tahun 2018 adalah 1,39. Tingkat Pertumbuhan Laba Pada PT.Kimia Farma (Persero) bersih tahun 2019 sebesar Rp. 4.780 .373 dan laba bersih 2018 sebesar Rp. 775.702.104.

\section{Gambar 4}

\section{Pertumbuhan Laba pada tahun 2019}

$$
\begin{aligned}
\text { Pertumbuhan Laba } & =\frac{4.780 .373-775.702 .104}{775.702 .104} \times 100 \% \\
& =0,99
\end{aligned}
$$

Pertumbuhan Laba pada PT.

Kimia Farma (Persero) Tbk pada tahun 2019 adalah 0,99. Berdasarkan hasil perhitungan pertumbuhan laba PT. Kimia Farma (Persero) Tbk selama 5 (lima) tahun dapat dilihat bahwa Pada tahun 2014-2015 perusahaan PT. Kimia Farma (Persero) Tbk menunjukan hasil dari pertumbuhan laba sebesar -0,28, pada tahun 2015-2016 perusahaan PT. Kimia Pada tahun 2017-2018, perusahaan PT. Kimia Farma (Persero) Tbk memiliki hasil daripertumbuhan laba meningkat sebesar 1,39 dan pada tahun 2018-2019 perusahaan PT. Kimia Farma (Persero) Tbk memiliki hasil dari pertumbuhan laba menurun sebesar 0,99.

Farma (Persero) Tbk memiliki hasil dari pertumbuhan laba yang cukup meningkat sebesar 0,31, pada tahun 2016- 2017 perusahaan PT. Kimia Farma (Persero) Tbk memiliki hasil yang sama dengan tahun sebelumnya yaitu sebesar 0,31 . 
Tabel 4.3

Analisis Return On Assets Dalam Menilai Pertumbuhan Laba pada PT Kimia Farma (Persero) Tbk.

\begin{tabular}{|l|c|c|l|}
\hline Tahun & $\begin{array}{c}\text { Return On Assets } \\
(\mathbf{X})\end{array}$ & $\begin{array}{c}\text { pertumbuhan } \\
\text { laba (Y) }\end{array}$ & $\begin{array}{l}\text { Kontribusi } \\
(\mathbf{Y : X )}\end{array}$ \\
\hline 2015 & $58,07 \%$ & $-0,28$ & $-0,004 \%$ \\
\hline 2016 & $53,52 \%$ & 0,31 & $0,005 \%$ \\
\hline 2017 & $53,12 \%$ & 0,31 & $0,005 \%$ \\
\hline 2018 & $81,99 \%$ & 1,39 & $0,016 \%$ \\
\hline 2019 & $0,26 \%$ & 0,99 & $3,807 \%$ \\
\hline Rata-rata & $\mathbf{4 9 , 3 9 \%}$ & $\mathbf{0 , 5 4}$ & $\mathbf{0 , 7 6 \%}$ \\
\hline
\end{tabular}

Sumber: Data Diolah Laporan Keuangan PT. Kimia Farma (Persero) Tbk.

Berdasarkan tabel 4.3 Kontribusi perputaran Return On Assetsdengan pertumbuhan laba pada PT. Kimia Farma (Persero) Tbk pada tahun 2015 sampai dengan 2019 cenderung mengalami peningkatan pada tahun 2019. Pada tahun 2015 kontribusi kontribusi sebesar,
0,004\% dan pada tahun 2016 mengalami peningkatan sebesar $0,001 \%$. Pada tahun 2017 mengalami penetapan angka dari tahun sebelumnya yaitu sebesar $0,005 \%$. Peningkatan dialami lagi di tahun 2018 sebesar 0,011\%. Pada tahun 2019 mengalami peningkatan sebesar $3,791 \%$.

Tabel 4.4

Perkembangan Return On Assets PT. Kimia Farma (Persero) Tbk.

\begin{tabular}{|c|l|l|}
\hline Return On Assets & Naik (Turun) & Kriteria \\
\hline $58,07 \%$ & - & - \\
\hline $53,52 \%$ & 4,55 & Penurunan \\
\hline $53,12 \%$ & $(0,4)$ & Penurunan \\
\hline $81,99 \%$ & $-28,87$ & Peningkatan \\
\hline $0,26 \%$ & 81,73 & Penurunan \\
\hline
\end{tabular}


Sumber: Data Diolah Laporan Keuangan PT. Kimia Farma (Persero) Tbk.

Return On Assets (ROA) Menunjukkan kemampuan perusahaan dengan menggunakan seluruh aktiva yang dimiliki untuk menghasilkan laba setelah pajak, rasio ini penting bagi pihak manajemen untuk mengevaluasi efektivitas dan efisiensi manajemen perusahaan dalam mengelola seluruh aktiva perusahaan. Semakin besar ROA, berarti semakin efisien penggunaan aktiva perusahaan atau dengan kata lain dengan jumlah aktiva yang sama bisa dihasilkan laba yang lebih besar dan sebaliknya.

Berdasarkan tabel 4.4 nilai ROA PT. Kimia Farma (Persero) Tbk periode 2015 sampai 2019 berfluktuasi dan terjadi penurunan pada tahun 2013 yaitu 58,07\%, $53,52 \%, 53,12 \%, 81,99 \%, 0,26 \%$. Naik turunnya ROA disebabkan oleh laba pada penjualan yang tidak stabil, kemudian disusul oleh penurunan pada perputaran total aktiva. Penurunan ini menandakan bahwa perusahaan semakin tidak efektif dalam mengelola harta untuk menghasilkan laba. Jika dibandingkan dengan rata-rata industri perusahaan, periode 2015 sampai 2018 PT. Kimia Farma (Persero) Tbk dikatakan baik karena berada diatas rata-rata industri tetapi pada periode 2019 perputaran ROA menurun dan dikatakan kurang efektif nya pengelolaan harta pada PT. Kimia Farma (Persero) Tbk.

Tabel 4.5

Perkembangan Pertumbuhan Laba pada PT Kimia Farma (Persero) Tbk.

\begin{tabular}{|c|l|l|}
\hline Pertumbuhan Laba & Naik (Turun) & Keterangan \\
\hline$-0,28$ & - & - \\
\hline 0,31 & $-0,59$ & Peningkatan \\
\hline 0,31 & 0 & Peningkatan \\
\hline 1,39 & 1,08 & Peningkatan \\
\hline 0,99 & 0,4 & Penurunan \\
\hline
\end{tabular}

Sumber: (data diolah) Laporan Keuangan PT. Kimia Farma (Persero)Tbk.

Berdasarkan tabel 4.5 nilai pertumbuhan laba pada tahun 2015 pertumbuhan laba yang diukur dengan rasio pertumbuhan laba pada PT. Kimia 
Farma (Persero) Tbk sebesar -0,28. Pada tahun 2016 pertumbuhan laba yang diukur dengan rasio pertumbuhan laba pada PT. Kimia Farma (Persero) Tbk sebesar 0.31. Sehingga pada tahun ini pertumbuhan laba PT. Kimia Farma (Persero) Tbk mengalami peningkatan $-0,59$ dari tahun sebelumnya $-0,28$. Hal ini disebabkan oleh laba bersih berjalan pada PT. Kimia Farma (Persero) Tbk mengalami peningkatan jauh lebih tinggi dari tahun sebelumnya. Sehingga dapat dikatakan bahwa perusahaan mampu mengelola laba bersih berjalan secara efisien untuk menilai laba. (Marpaung, 2021b)

Pada tahun 2017 pertumbuhan laba yang diukur dengan rasio pertumbuhan laba pada PT. Kimia Farma (Persero) Tbk sebesar 0,31 . Sehingga pada tahun ini pertumbuhan laba PT. Kimia Farma (Persero) Tbk mengalami penurunan sebesar 0. Hal ini disebabkan oleh laba bersih berjalan pada PT. Kimia Farma (Persero) Tbk mengalami peningkatan jauh lebih tinggi dari tahun

sebelumnya. Sehingga dapat dikatakan bahwa perusahaan mampu mengelola laba bersih berjalan secara efisien untuk menilai laba.

Pada tahun 2018 pertumbuhan laba yang diukur dengan rasio pertumbuhan laba pada PT. Kimia Farma (Persero) Tbk sebesar 1,39. Sehingga pada tahun ini pertumbuhan laba PT. Kimia Farma (Persero) Tbk mengalami peningkatan 1,08 dari tahun sebelumnya 0 . Hal ini disebabkan oleh laba bersih berjalan pada PT. Kimia Farma (Persero) Tbk mengalami peningkatan jauh lebih tinggi dari tahun sebelumnya. Sehingga dapat dikatakan bahwa perusahaan mampu mengelola laba bersih berjalan secara efisien untuk menilai laba.

Pada tahun 2019 pertumbuhan laba yang diukur dengan rasio pertumbuhan laba pada PT. Kimia Farma (Persero) Tbk sebesar 0,99. Sehingga pada tahun ini pertumbuhan laba PT. Kimia Farma (Persero) Tbk mengalami penurunan sebesar 0,4. Hal ini disebabkan oleh laba bersih sebelumnya lebih tinggi dari tahun sebelumnya, dengan diikuti laba bersih berjalan yang lebih rendah. Sehingga dapat dikatakan bahwa perusahaan kurang mampu mengelola laba bersih berjalan secara efisien. 
Tabel 4.9

Analisis Return On AssetsDalam Menilai Pertumbuhan Laba Pada PT. Kimia Farma (Persero) Tbk.

(dalam jutaan rupiah)

\begin{tabular}{|c|c|c|c|}
\hline Tahun & Return On Assets & pertumbuhan & Kontribusi \\
& $(\mathbf{X})$ & laba (Y) & $(\mathbf{Y}: \mathbf{X})$ \\
\hline 2015 & $58,07 \%$ & $-0,28$ & $-0,004 \%$ \\
\hline 2016 & $53,52 \%$ & 0,31 & $0,005 \%$ \\
\hline 2017 & $53,12 \%$ & 0,31 & $0,005 \%$ \\
\hline 2018 & $81,99 \%$ & 1,39 & $0,016 \%$ \\
\hline 2019 & $0,26 \%$ & 0,99 & $3,807 \%$ \\
\hline Rata-rata & $\mathbf{4 9 , 3 9 \%}$ & $\mathbf{0 , 5 4}$ & $\mathbf{0 , 7 6 \%}$ \\
\hline
\end{tabular}

Sumber: Data Diolah Laporan Keuangan PT. Kimia Farma (Persero)Tbk.

Berdasarkan tabel diatas dapat di katakan bahwa pada tahun 2015 perubahan perputaran Return On Assetssetiap 1,00 akan diikuti dengan $-0,004 \%$ perubahan Pertumbuhan Laba. pada tahun 2016 perubahan perputaran Return On Assetssetiap 1,00 akan diikuti dengan 0,005\% perubahan Pertumbuhan Laba. pada tahun 2017 perubahan perputaran Return On Assetssetiap 1,00 akan diikuti dengan $0,005 \%$ perubahanPertumbuhan Laba. Pada tahun

2018 perubahan perputaran Return On
Assetssetiap 1,00 akan diikuti dengan 0,016\% perubahan Pertumbuhan Laba. pada tahun 2019 perubahan perputaran Return On Assetssetiap 1,00 akan diikuti dengan $3,807 \%$ perubahan Pertumbuhan Laba.

\section{KESIMPULAN}

Hasil pengujian analisis Return On Assets dalam menilai Pertumbuhan laba pada PT. Kimia Farma (Persero) Tbk yang diperoleh dari laporan keuangan PT. Kimia Farma (Persero) Tbk selama 5 periode dari tahun 2015-2019, 
berdasarkan hasil penelitian tersebut bahwa perputaran Return On Assets dalam menilai Pertumbuhan laba memiliki kontribusi sebesar $0,76 \%$. Hal ini dapat dibuktikan dengan hasil penelitian bahwa setiap perputaran Return On Assets mengalami perubahan sebesar 1 rupiah akan diikuti oleh perubahan Pertumbuhan laba rata-rata untuk periode 2015-2019 sebesar 0,54 yang berarti sangat signifikan Return On Assets dalam menilai Pertumbuhan laba.

\section{REFERENCES}

Devie Deviesa. 2019. Akuntansi Manajemen. Yogyakarta: ANDI.

Hery, S.., M.Si. 2016. Analisis Laporan Keuangan. Jakarta: PT. Grasindo Ikatan Akuntan Indonesia. Standar Akuntansi Keuangan. Jakarta: Salemba Empat.

Kasmir. 2016. Analisis Laporan Keuangan. Jakarta: PT. Rajagrafindo.

Kasmir. 2018. Analisis Laporan Keuangan. Depok: PT. Rajagrafindo.

Marpaung, N. N. (2021a). PENGARUH

KUALITAS PELAYANAN DAN

HARGA TERHADAP KEPUTUSAN PEMBELIAN AIR MINUM ISI ULANG "BIRU” DI JL. JEMBATAN 5 PONDOK TIMUR - KOTA BEKASI. PARAMETER, 5(1), 12-25. https://doi.org/10.37751/parameter.v $5 \mathrm{i} 1.136$
Marpaung, N. N. (2021b). ANALISIS PERPUTARAN KAS DALAM MENILAI RETURN ON ASSET PADA PT. PRASIDHA ANEKA NIAGA, Tbk. PARAMETER, 4(2). https://doi.org/10.37751/parameter.v $4 \mathrm{i} 2.155$

Sofyan Syarif Harahap. 2016. Analisis Kritis Laporan Keuangan. Jakarta: PT. Rajagrafindo.

Sri Suartini dan Hari Sulistiyo. 2017. Analisis Laporan Keuangan. Jakarta: Mitra Wacana Media

Toto Prihadi. 2019. Analisis Laporan Keuangan. Jakarta: PT. Gramedia Pustaka Utama.

V. Wiratna Sujarweni. 2017. Analisis Laporan Keuangan. Yogyakarta: Pustaka Baru Pres.

Prof. Dr. Dermawan Sjahrial,M.M. 2014. Manajemen Keuangan Lanjutan. Jakarta: Mitra Wacana Media.

Prof. Dr.Hamidah, S.E., M.Si. 2015. Manajemen Keuangan. Bogor: Mitra Wacana Media. 